\title{
Association between Depression Levels and Self-Perceived Oral Health among Medical Students
}

\author{
Miloš M. Stepović1, Zlata Rajković1, Dailbor Stajić2, Marija Sekulić \\ Milena Maričić 3 , Nela Đonovićé, \\ ${ }^{1}$ University of Kragujevac, Faculty of Medical Sciences, Kragujevac, Serbia \\ ${ }^{2}$ University of Kragujevac, Faculty of Medical Sciences, \\ Department of Hygiene and Ecology, Kragujevac, Serbia \\ ${ }^{3}$ Medical College of Applied Sciences in Zemun, Belgrade, Serbia \\ ${ }^{4}$ Institute for Public Health, Kragujevac, Serbia
}

SUMMARY

The aim of the study was to determine the correlation between depression levels, oral health, oral health habits and subjective feelings in the region of the mouth and teeth in senior medical students.

A total of 103 students at the final study year at the Faculty of Medical Science, University of Kragujevac, participated in the research. Two types of questionnaires were used in this research - Beck Depression Inventory-II and Oral Health Questionnaire for Adults. Statistical analysis was performed using SPSS, version 21. Chi-square test was performed and the results with p-value less than 0.05 were considered statistically significant.

There was no statistically significant difference between the levels of depression among genders. Twenty-one point four percent of students had depression. The correlation between depression levels and oral health variables showed that frequency of brushing teeth and avoiding smiling were significant between different levels of depression among females. The problems with biting food and problems in social interaction were significant among genders.

Depressive feelings were noticed among senior medical students and they affected their selfperceived oral health. Oral health promotion programs targeting the young population could help improving oral health behaviour.

Key words: depression, oral health, medical students, mental health, Serbia

Corresponding author:

Milos M. Stepović

E-mail: stepovicmilos@yahoo.com 


\section{INTRODUCTION}

The twenty-first century can be considered the century of depression as the number of persons with this mental disorder increase more every year (1). Although depression is mostly linked with elderly people due to their age and usually followed by comorbid diseases, the last decade demonstrated a significant increase in these numbers in younger people as well (2). Everyday responsibilities and competence present in every area of life can be stressful. Coping with stress and pressure on daily basis can be very hard to handle in young people and may be followed with feelings of isolation and early signs of depression (3). Depression is also associated with increased number of suicides and the recognition of this mental disorder in early stages can prevent unfortunate cases (4). Few systematic reviews indicated that medical students often had suicidal ideation that varied from $5 \%$ to $35 \%(5)$.

Depression is usually followed by lower selfinterests that in early stages may be misjudged with the filling of sadness. The changed state of mind usually affects slowly every aspect of life in the sense of decreased personal self-care. In stages like this, it is not rare that these signs present in the oral cavity, firstly as avoidance of dental check-ups and later as the growing number of dental diseases. Oral cavities, gingivitis, and periodontal disease are the product of neglected oral health that usually follows depression (6). Compared to the developed countries, it has been shown that the frequency of tooth brushing is almost always lower in the developing countries (7).

A certain number of researches in the world described a psychological health status of medical students as unsatisfying (8-11). The underlying reasons were the duration of studies, concerns about the studies, pressure, and expectations of their surroundings. All these variables affected the perception of students' overall health, also including the oral health $(12,13)$. The most affected period of the studies is mostly the senior years in comparison to the freshman period, which can be explained by the fact that the stress usually increases as completion of studies draws near $(7,14)$.

Dental fear among students, as among the general population, is mostly present, but dental anxiety is more likely to be the issue that occur in female gender and it is often combined with depression symptoms (13). Due to depressive feelings, females are more likely to visit dentists seeking consultation than males. At the psychological levels, the oral health contributes to self-esteem, selfexpression, communication, facial aesthetics and the overall influence on the quality of a person's life, especially when subjective feelings (pain, chewing problems, and speaking problems) related to the mouth and teeth are concerned $(15,16)$.

The aim of this paper was to assess the selfperceived oral health, oral health habits and experienced oral health problems in senior year medical students experiencing different levels of depression and to identify the relation between these variables.

\section{METHODOLOGY}

This study included the senior year medical students at the Faculty of Medical Sciences, University of Kragujevac, Serbia. Permission to conduct this research was in accordance with the local legislation and institutional requirements of the Faculty of Medical Science. Questionnaires were handed out after the regular lectures, with approval of the professors and acceptance of students to participate in the study. Partially filled questionnaires were not assessed.

Beck Depression Inventory-II (BDI-II) was used to assess the presence of depression symptoms in all participants. The 21 depressive symptoms and attitudes included in the BDI-II are sadness, pessimism, past failure, loss of pleasure, feeling guilty, punishment feelings, self-dislike, self-criticism, suicidal thoughts or wishes, crying, agitation, loss of interest, indecisiveness, worthlessness, loss of energy, changes in sleeping pattern, irritability, changes in appetite, concentration difficulty, tiredness or fatigue, and loss of interest in sex. Each item is rated on a 4-point Likert-type scale ranging from 0 to 3 , based on the severity in the last two weeks. The total score ranges from 0 to 63 , with higher scores indicating more severe depressive symptoms. Beck's scale includes 21 questions and is designed as an instrument that patients fill in. The score 0-13 indicates minimal depression, 14-19 indicates mild depression, 20-28 indicates moderate depression and the score over 28 points to severe depression $(17,18)$.

Oral Health Questionnaire for Adults recommended by the World Health Organisation 
Table 1. Self-assessment of oral health, oral health habits and perception of teeth and gums health according to the level of depression

\begin{tabular}{|c|c|c|c|c|c|c|c|c|c|c|c|}
\hline & \multicolumn{2}{|c|}{$\begin{array}{l}\text { Minimal BDI- } \\
\text { II range }\end{array}$} & \multicolumn{2}{|c|}{$\begin{array}{l}\text { Mild BDI-II } \\
\text { range }\end{array}$} & \multicolumn{2}{|c|}{$\begin{array}{l}\text { Moderate BDI- } \\
\text { II range } \\
\end{array}$} & \multicolumn{2}{|c|}{$\begin{array}{c}\text { Severe BDI-II } \\
\text { range }\end{array}$} & \multicolumn{3}{|c|}{$P$ - value } \\
\hline & $\mathrm{M} \%$ & $\mathrm{~F} \%$ & $\mathrm{M} \%$ & $\mathrm{~F} \%$ & $\mathrm{M} \%$ & $\mathrm{~F} \%$ & $\mathrm{M} \%$ & $\mathrm{~F} \%$ & $\mathrm{M}$ & $\mathrm{F}$ & Total \\
\hline \multicolumn{12}{|c|}{ The number of natural teeth } \\
\hline $10-19$ & 0 & 0 & 0 & 0 & 0 & 0 & 0 & 0 & \multirow{3}{*}{0.308} & \multirow{3}{*}{0.393} & \multirow{3}{*}{0.525} \\
\hline $20-28$ & 14.6 & 19.4 & 0 & 1.6 & 2.4 & 0 & 0 & 0 & & & \\
\hline $29-32$ & 70.7 & 54.8 & 9.8 & 16.1 & 2.4 & 6.5 & 0 & 1.6 & & & \\
\hline \multicolumn{12}{|l|}{ Feeling pain/discomfort } \\
\hline Yes & 29.3 & 22.6 & 4.9 & 3.2 & 2.4 & 1.6 & 0 & 1.6 & \multirow{3}{*}{0.902} & \multirow{3}{*}{0.195} & \multirow{3}{*}{0.438} \\
\hline No & 46.3 & 43.5 & 4.9 & 12.9 & 2.4 & 1.6 & 0 & 0 & & & \\
\hline I don't know & 9.8 & 8.1 & 0 & 1.6 & 0 & 3.2 & 0 & 0 & & & \\
\hline \multicolumn{12}{|c|}{ Frequency of tooth brushing } \\
\hline $2-6$ times per week & 2.4 & 0 & 0 & 0 & 0 & 0 & 0 & 0 & \multirow{3}{*}{0.432} & \multirow{3}{*}{0.031} & \multirow{3}{*}{0.163} \\
\hline Once daily & 7.3 & 0 & 2.4 & 1.6 & 2.4 & 1.6 & 0 & 0 & & & \\
\hline 2 and more times daily & 75.6 & 74.2 & 7.3 & 16.1 & 2.4 & 4.8 & 0 & 1.6 & & & \\
\hline \multicolumn{12}{|c|}{$\begin{array}{l}\text { Does your toothpaste has } \\
\text { fluoride }\end{array}$} \\
\hline Yes & 53.7 & 53.2 & 7.3 & 11.3 & 4.9 & 0 & 0 & 0 & \multirow{2}{*}{0.515} & \multirow{2}{*}{0.081} & \multirow{2}{*}{0.499} \\
\hline I don't know & 31.7 & 21 & 2.4 & 6.5 & 0 & 6.5 & 0 & 1.6 & & & \\
\hline \multicolumn{12}{|l|}{ Last dental visit } \\
\hline Less than 1 year & 58.5 & 61.2 & 4.9 & 14.6 & 4.8 & 6.6 & 0 & 1.6 & \multirow{3}{*}{0.311} & & \\
\hline $1-2$ years & 9.8 & 9.7 & 4.9 & 1.6 & 0 & 0 & 0 & 0 & & 0.468 & 0.529 \\
\hline More than 2 years & 17.1 & 3.2 & 0 & 1.6 & 0 & 0 & 0 & 0 & & & \\
\hline The reason of the last dento & & & & & & & & & & & \\
\hline Consultation & 14.6 & 4.8 & 0 & 6.5 & 0 & 0 & 0 & 0 & & & \\
\hline Pain & 36.6 & 22.6 & 2.4 & 3.2 & 0 & 1.6 & 0 & 1.6 & $0 \sqsubset 00$ & 0100 & ר? \\
\hline Appointment & 19.5 & 21 & 4.9 & 4.8 & 2.4 & 0 & 0 & 0 & 0.588 & 0.109 & 0.292 \\
\hline Regular checkup & 14.6 & 25.8 & 2.4 & 3.2 & 2.4 & 24.8 & 0 & 0 & & & \\
\hline Do you smoke? & & & & & & & & & & & \\
\hline Yes & 34.1 & 16.1 & 4.9 & 6.5 & 0 & 3.2 & 0 & 0 & 0172 & 0456 & O 777 \\
\hline No & 51.5 & 58.1 & 4.9 & 11.3 & 4.9 & 3.2 & 0 & 1.6 & 0.473 & 0.456 & 0.777 \\
\hline $\begin{array}{l}\text { How many drinks hat } \\
\text { used in last } 30 \text { days? }\end{array}$ & & & & & & & & & & & \\
\hline $1-3$ drinks & 44 & 37.1 & 2.4 & 9.7 & 4.9 & 3.2 & 0 & 0 & & & \\
\hline $4-5$ drinks & 19.5 & 9.7 & 4.9 & 0 & 0 & 0 & 9 & 0 & 0.299 & 0.696 & 0.571 \\
\hline I don't consume & 22 & 27.4 & 2.4 & 8.1 & 0 & 3.2 & 0 & 1.6 & & & \\
\hline $\begin{array}{l}\text { How would you rank } \\
\text { dental health? }\end{array}$ & & & & & & & & & & & \\
\hline Good & 63.4 & 53.2 & 2.4 & 11.3 & 2.4 & 6.5 & 0 & 0 & & & \\
\hline Average & 17.1 & 17.7 & 7.3 & 4.8 & 2.4 & 0 & 0 & 1.6 & 0.185 & 0.502 & 0.428 \\
\hline Bad & 4.9 & 3.2 & 0 & 1.6 & 0 & 0 & 0 & 0 & & & \\
\hline $\begin{array}{l}\text { How would you rank } \\
\text { gum health? }\end{array}$ & & & & & & & & & & & \\
\hline Good & 63.4 & 56.5 & 7.3 & 12.9 & 2.4 & 4.8 & 0 & 0 & & & \\
\hline Average & 14.6 & 14.5 & 2.4 & 3.2 & 2.4 & 1.6 & 0 & 1.6 & 0.775 & 0.604 & 0.545 \\
\hline Bad & 7.3 & 3.2 & 0 & 1.6 & 0 & 0 & 0 & 0 & & & \\
\hline
\end{tabular}


Table 2. Subjectivly experienced problems due to the state of teeth and mouth according to the level of depression

\begin{tabular}{|c|c|c|c|c|c|c|c|c|c|c|c|}
\hline & \multicolumn{2}{|c|}{$\begin{array}{l}\text { Minimal BDI- } \\
\text { II range }\end{array}$} & \multicolumn{2}{|c|}{$\begin{array}{l}\text { Mild BDI-II } \\
\text { range }\end{array}$} & \multicolumn{2}{|c|}{$\begin{array}{l}\text { Moderate BDI- } \\
\text { II range }\end{array}$} & \multicolumn{2}{|c|}{$\begin{array}{l}\text { Severe BDI-II } \\
\text { range }\end{array}$} & \multicolumn{3}{|c|}{$P$ - value } \\
\hline & $\mathrm{M} \%$ & $\mathrm{~F} \%$ & $\mathrm{M} \%$ & $\mathrm{~F} \%$ & $\mathrm{M} \%$ & $\mathrm{~F} \%$ & $\mathrm{M} \%$ & $\mathrm{~F} \%$ & $\mathrm{M}$ & $\mathrm{F}$ & Total \\
\hline \multicolumn{12}{|c|}{ Difficulty in biting food } \\
\hline Often & 4.9 & 3.2 & 0 & 1.6 & 0 & 0 & 0 & 1.6 & \multirow{3}{*}{0.710} & \multirow{3}{*}{0.003} & \multirow{3}{*}{0.002} \\
\hline Sometimes & 12.2 & 1.6 & 2.4 & 1.6 & 2.4 & 1.6 & 0 & 0 & & & \\
\hline No & 68.3 & 69.4 & 7.3 & 14.5 & 2.4 & 4.8 & 0 & 0 & & & \\
\hline \multicolumn{12}{|c|}{ Difficulty chewing foods } \\
\hline Often & 2.4 & 1.6 & 0 & 1.6 & 0 & 0 & 0 & 0 & \multirow{3}{*}{0.435} & \multirow{3}{*}{0.107} & \multirow{3}{*}{0.207} \\
\hline Sometimes & 12.2 & 6.5 & 4.9 & 1.6 & 0 & 1.6 & 0 & 1.6 & & & \\
\hline No & 70.7 & 66.1 & 4.9 & 14.5 & 4.9 & 4.8 & 0 & 0 & & & \\
\hline \multicolumn{12}{|c|}{ Difficulty with speech } \\
\hline Often & 4.9 & 1.6 & 0 & 0 & 0 & 0 & 0 & 0 & \multirow{3}{*}{0.968} & \multirow{3}{*}{0.968} & \multirow{3}{*}{0.963} \\
\hline Sometimes & 2.4 & 8.1 & 0 & 1.6 & 0 & 0 & 0 & 0 & & & \\
\hline No & 78 & 64.5 & 9.8 & 16.1 & 4.9 & 6.5 & 0 & 1.6 & & & \\
\hline \multicolumn{12}{|l|}{ Dry mouth } \\
\hline Often & 2.4 & 1.6 & 0 & 0 & 0 & 1.6 & 0 & 0 & \multirow{3}{*}{0.199} & \multirow{3}{*}{0.125} & \multirow{3}{*}{0.210} \\
\hline Sometimes & 43.1 & 17.7 & 0 & 6.5 & 4.9 & 1.6 & 0 & 1.6 & & & \\
\hline No & 48.8 & 54.8 & 9.8 & 11.3 & 0 & 3.2 & 0 & 0 & & & \\
\hline \multicolumn{12}{|c|}{ Have you felt embarrassed } \\
\hline Often & 2.4 & 3.2 & 0 & 0 & 0 & 0 & 0 & 0 & & & \\
\hline Sometimes & 9.8 & 8.1 & 4.9 & 4.8 & 2.4 & 0 & 0 & 1.6 & 0.244 & 0.168 & 0.093 \\
\hline No & 73.2 & 62.9 & 4.9 & 12.9 & 2.4 & 6.5 & 0 & 0 & & & \\
\hline Have you fel & & & & & & & & & & & \\
\hline Often & 2.4 & 4.8 & 0 & 1.6 & 0 & 0 & 0 & 0 & & & \\
\hline Sometimes & 17.1 & 11.3 & 2.4 & 6.5 & 0 & 4.8 & 0 & 1.6 & 0944 & 0062 & 0191 \\
\hline No & 65.9 & 58.1 & 7.3 & 19.7 & 4.9 & 1.6 & 0 & 0 & 0.944 & 0.062 & 0.191 \\
\hline Have you avo & & & & & & & & & & & \\
\hline Often & 4.9 & 3.2 & 0 & 1.6 & 0 & 0 & 0 & 0 & & & \\
\hline Sometimes & 17.1 & 4.8 & 0 & 6.5 & 2.4 & 1.6 & 0 & 1.6 & 0.631 & 0.032 & 0.184 \\
\hline No & 63.4 & 66.1 & 9.8 & 9.7 & 2.4 & 4.8 & 0 & 0 & & & \\
\hline $\begin{array}{r}\text { Have you ha } \\
\text { sl }\end{array}$ & & & & & & & & & & & \\
\hline Often & 4.9 & 1.6 & 0 & 3.2 & 0 & 0 & 0 & 0 & & & \\
\hline Sometimes & 9.8 & 11.3 & 0 & 1.6 & 0 & 1.6 & 0 & 0 & 0.877 & 0.444 & 0.742 \\
\hline No & 70.7 & 61.3 & 9.8 & 12.9 & 4.9 & 4.8 & 0 & 1.6 & & & \\
\hline $\begin{array}{r}\text { Have you to } \\
w\end{array}$ & & & & & & & & & & & \\
\hline Often & 0 & 1.6 & 0 & 0 & 0 & 0 & 0 & 0 & & & \\
\hline Sometimes & 12.2 & 3.2 & 0 & 1.6 & 0 & 1.6 & 0 & 0 & 0.614 & 0.793 & 0.988 \\
\hline No & 73.2 & 69.4 & 9.8 & 16.1 & 4.9 & 4.8 & 0 & 1.6 & & & \\
\hline $\begin{array}{l}\text { Reduced pai } \\
\text { social activi }\end{array}$ & & & & & & & & & & & \\
\hline Often & 0 & 3.2 & 0 & 0 & 0 & 0 & 0 & 0 & & & \\
\hline Sometimes & 9.8 & 3.2 & 2.4 & 1.6 & 0 & 0 & 0 & 1.6 & 0.635 & 0.014 & 0.049 \\
\hline No & 75.6 & 67.7 & 7.3 & 16.1 & 4.9 & 6.5 & 0 & 0 & & & \\
\hline
\end{tabular}


was used to assess the self-perceived oral health, oral health conditions, and oral health habits. It contains 16 questions about oral health habits, oral health condition, frequency of dental visit and subjective feeling of the oral condition (19).

Data was analysed using the Statistical Package for Social Sciences Software, version 21 (SPSS, Chicago, Illinois, version 21.0). Frequency tables were generated for the descriptive data. A chisquare test was used to assess the correlation between variables. The level of significance was determined as $\mathrm{p}<0.05$.

\section{RESULTS}

The total number of participants was 122, but due to incomplete questionnaires, 19 participants were not considered in the final result calculation. The final number of participants was 103 out of whom 41 (39.8\%) were males and 62 (62.2\%) were females. The average age of participants was 24.62 years. When analysing the difference in BDI scale and gender, statistical difference was not observed. Minimal depression was found in $78.6 \%$ of participants (34.0\% males and $44.7 \%$ females); mild depression was found in $14.6 \%$ of participants $(3.9 \%$ males and $10.7 \%$ females); moderate depression was found in $5.8 \%$ of participants $(1.9 \%$ males and $3.9 \%$ females); severe depression was found in $1 \%$ (no males and $1 \%$ female).

Cross tabulation was used to assess the correlation between the BDI-II level of depression and the variables about oral health, oral habits and subjective experience of problems that occur as a result of discomfort in the mouth and teeth. Statistical significance was found between the female participants experiencing different levels of depression that influences the frequency of tooth brushing ( $p-0.031)$, but there was no statistical significance between genders (Table 1). When subjectively experienced problems were correlated with the level of depression, the statistical significance was found between genders in difficulty in biting food ( $\mathrm{p}-0.002)$ and reduced participation in social activities $(\mathrm{p}-0.049)$. The difference between females experiencing different level of depression was found in food biting ( $\mathrm{p}-0.003)$, reduced participation in social activities $(\mathrm{p}-0.014)$ and also in avoiding smiling $(\mathrm{p}-0.032)$ (Table 2$)$.

\section{DISCUSSION}

Depression increases among students of the final year and it is not uncommon, although in the minority of this population it persist later in life (20). In our research, every fifth student was feeling depressed (21.4\%). In the study of Reddy et al. (21), the largest number of participants in the senior year had mild depression, which is in agreement with our results. Psychological distress levels in depressed people vary and many researchers have found that it occurs more often in females $(22,23)$. Numerous researchers obtained the opposite results, showing no differences between the genders when depression was assessed (24). Differences among dental and medical students were more observed in the female medical students as the levels of stress and depression were higher (25). This is in line with our findings where female medical students had higher level of depression than male students. The results obtained by Alregal et al. (26) showed that positive oral health behaviour among females was higher than in males. Our research showed no statistical difference in the frequency of tooth brushing among genders, but females, at different levels of depression, brushed teeth more frequently than males. Studies have shown that depressed female patients had more frequent tooth brushing, dental floss use and more often dental check-ups $(27,28)$. This agrees with our results, and the main reason for dental check-ups in females was a regular visit or pain. In low and middle-income countries, the association between poor mental health and lower development of countries results in fewer tooth brushing and less than one annual dental care visit (29). As Serbia belongs to the higher middle-income countries, our results are expectedly different and the highest percent of medical students brushed teeth twice and more daily, and had their dental visit in less than one year. Quality of life is very important aspect in today's research as it measures the expectations of an individual or society for a good life. The presence of oral condition affects the quality of life and as the subjective feeling in depressed patients is changed, this group of people had lower scores in the quality of life assessments (30). Subjective feelings related to oral conditions in depressed patients such as biting, chewing, speaking 
or even a lowering level of social interaction, because the condition of their teeth partly influenced the quality of their life. Kim et al. (31) found the chewing problems in depressed patients, however, discomfort during speaking was only associated with higher level of stress. Our study found the correlation between genders with different depression levels in biting food and social interaction, but also the problem with smiling in females.

Depression is a chronic mental illness that affects both genders and all age groups. Duration of depression differs from several weeks to the life-time depending on the life-style factors and presence or absence of the needed treatment. Our research showed that depression is present among the students of the senior year and that it affects oral health in a certain way. It affects the frequency of tooth brushing at different levels of depression in females and subjective feelings among genders, like chewing problems and social isolation. As depression may persist very long and affects the person's life in every aspect, it is crucial to be detected on time. Oral health promotion programs targeting the young population could help to improve their attitude and oral health behaviour.

The advantages of the study are that this study is one of the few studies conducted in Serbia on the university student population, targeting senior students. Senior students are at an increased risk of suffering from depression symptoms which could lead to the development of depression and as- sociated oral health problems. University population is composed of young adult people who are becoming important parts of society after graduating, so the necessity of tracking their mental state is of great importance. This study could be a potential trigger that could awake interest in conducting similar research with focus on mental hygiene of the student population.

A possible limitation of the study is that it involved only the senior students. It is a crosssectional study, so conducting research on a certain population like freshmen and following them through their university education could better show a possible pattern of depression development and associated oral health problems. Also, the limitations of the study also refer to the fact that the research included only medical students and not the students from other faculties with different areas of interest, which could form the pattern of development of depression in different study environments.

\section{Author contributions}

M.M.S., Z.R., D.S., M.S., M.M. and N.Dj. are all responsible for the design and conception, writing the article, critical revision of the article, final approval of the manuscript, and overall responsibility.

\section{Conflict of interest}

There is no conflict of interest among authors. 


\section{References}

1. World Health Organization. Depression. Geneva: WHO; (2018) Available online at:

http://www.who.int/news-room/fact-

sheets/detail/depression (Accessed May, 12 2019)

2. Hybels CF, Bennett JM, Landerman LR, et al. Trajectories of depressive symptoms and oral health outcomes in a community sample of older adults. Int J Geriatr Psychiatry 2015; 31: 83-91. https://doi.org/10.1002/gps.4292

3. Aktekin M, Karaman T, Senol YY, Erdem S, Erengin H, Akaydin M. Anxiety, depression and stressful life events among medical students: a prospective study in Antalya, Turkey. Med Educ 2001; 35(1): 12-7.

https://doi.org/10.1046/j.1365-2923.2001.00726.x

4. Bachmann S. Epidemiology of Suicide and the Psychiatric Perspective. Int J Environ Res Public Health 2018; 15: 1425.

https://doi.org/10.3390/ijerph15071425

5. Rotenstein LS, Ramos MA, Torre M, et al. Prevalence of Depression, Depressive Symptoms, and Suicidal Ideation Among Medical Students. JAMA 2016; 316(21): 2214.

https://doi.org/10.1001/jama.2016.17324

6. Delgado-Angulo EK, Sabbah W, Suominen Al, et al. The association of depression and anxiety with dental caries and periodontal disease among Finnish adults. Community Dent Oral Epidemiol 2015; 43: 540-9.

https://doi.org/10.1111/cdoe.12179

7. Sharda AJ, Shetty S. A comparative study of oral health knowledge, attitude and behaviour of first and final year dental students of Udaipur city, Rajasthan, India. Int J Dent Hyg 2008; 6: 347-53. https://doi.org/10.1111/j.1601-5037.2008.00308.x
8. Elani H, Allison P, Kumar R, et al. A Systematic Review of Stress in Dental Students. J Dent Educ 2014; 78(2): 226-42.

9. Ishak W, Nikravesh R, Lederer S, et al. Burnout in medical students: a systematic review. Clin Teach 2013; 10(4): 242-5. https://doi.org/10.1111/tct.12014

10. Dyrbye L, Thomas M, Shanafelt T. Systematic review of depression, anxiety, and other indicators of psychological distress among US and Canadian medical students. Acad Med 2006; 81(4): 354-73.

https://doi.org/10.1097/00001888-200604000-00009

11. Alzahem A, Van Der Molen H, Alaujan A, et al. Stress amongst dental students: A systematic review. Eur J Dent Educ 2011; 15(1): 8-18. https://doi.org/10.1111/j.1600-0579.2010.00640.x

12. Salgar S. Stress in first year medical students. Inter J Biomed Advan Res 2014; 5(1): 05-06. https://doi.org/10.7439/ijbar.v5i1.580

13. Sani M, Mahfouz M, Bani I, et al.. Prevalence of stress among medical students in Jizan University, Kingdom of Saudi Arabia. Gulf Med J 2012; 1(1): 19-25.

14. Silverstein S, Kritz-Silverstein D. A longitudinal study of stress in first-year dental students. J Dent Educ 2010; 74(8): 836-48.

15. Sravani A, Doshi D, Kulkarni S, et al. Depression, anxiety, and stress among undergraduate dental students in Hyderabad City, Telangana, India: A cross-sectional study. J Indian Assoc Public Health Dent. 2018; 16: 26-9.

https://doi.org/10.4103/jiaphd.jiaphd 1017 
16. Halonen $H$, Salo $T$, Hakko $H$, Räsänen P. The Association between Dental Anxiety, General Clinical Anxiety and Depression among Finnish University Students. Oral Health Dent Manag 2014; 13(2):320-5.

17. Strunk KK, Lane FC. The Beck Depression Inventory, Second Edition (BDI-II). Measurement and Evaluation in Counseling and Development 2016. https://doi.org/10.1177/0748175616664010

18. Zhang AY, Gary F. Discord of Measurements in Assessing Depression among African Americans with Cancer Diagnoses. Int J Cult Ment Health 2013; 6(1): 58-71.

https://doi.org/10.1080/17542863.2011.623042

19. World Health Organization. Oral Health Questionnaire for Adults. Geneva: WHO (2013) Available online at: https://www.who.int/oral health/publications/ pepannex7sohqbasicmethods.pdf?ua=1 (Accessed May, 12 2019)

20. Quince T, Wood D, Parker R, Benson J. Prevalence and persistence of depression among undergraduate medical students: a longitudinal study at one UK medical school. BMJ Open 2012; 2(4).

https://doi.org/10.1136/bmjopen-2012-001519

21. Reddy DV, Prabu NN, Manipal S, Preethi AA. The Evaluation of Perceived Stress and Depression in Dental Undergraduates. Intern Dent J Stud Res 2013; $1: 4$.

22. Jadoon N, Yaqoob R, Raza A, et al. Anxiety and depression among medical students: a crosssectional study. J Pak Med Assoc 2010; 60(8): 699702.

23. Samaranayake C, Fernando A. Satisfaction with life and depression among medical students in Auckland, New Zealand. N Z Med J 2011; 124(1341): 12-7.

24. Niemi P, Vainiomäki P. Medical students' distress-quality, continuity and gender differences during a six-year medical programme. Med Teach 2006; 28(2): 136-41.

https://doi.org/10.1080/01421590600607088

25. Aboalshamat K, Hou XY, Strodl E. Psychological Health of Medical and Dental Students in Saudi Arabia: A Longitudinal Study. Pub Health Res 2014; 4(5): 179-84.

https://doi.org/10.24966/CMPH-1978/100001

26. Alregal EN, Abdelgawad F, Sasahara H, El Motayam K. The level of education and oral health attitudes of the dental students in a governmental university - A crosssectional study. Int Dent Med J Adv Res 2018; 4: 1-7.

https://doi.org/10.15713/ins.idmjar.90

27. Anttila S, Knuuttila M, Ylostalo P, Joukamaa M. Symptoms of depression and anxiety in relation to dental health behavior and self-perceived dental treatment need. Eur J Oral Sci 2006; 114(2): 109114.

https://doi.org/10.1111/j.1600-0722.2006.00334.x

28. Marques-Vidal P, Milagre V. Are oral health status and care associated with anxiety and depression? A study of Portuguese health science students. J Public Health Dent 2006; 66(1): 64-6.

https://doi.org/10.1111/j.1752-7325.2006.tb02553.x

29. Peltzer K, Pengpid S. Oral Health Behaviour and Social and Health Factors in University Students from 26 Low, Middle and High Income Countries. International Int J Environ Res Public Health 2014; 11(12): 12247-60.

https://doi.org/10.3390/ijerph111212247

30. Burckhardt CS, Anderson KL. The Quality of Life Scale (QOLS): Reliability, Validity, and Utilization. Health Qual Life Outcomes 2003; 1(1): 60. https://doi.org/10.1186/1477-7525-1-60

31. Kim YS, Kim H-N, Lee JH, et al. Association of stress, depression, and suicidal ideation with subjective oral health status and oral functions in Korean adults aged 35 years or more. BMC Oral Health 2017; 17: 101. https://doi.org/10.1186/s12903-017-0391-4 


\title{
Povezanost nivoa depresije i samoprocene oralnog zdravlja kod studenata medicine
}

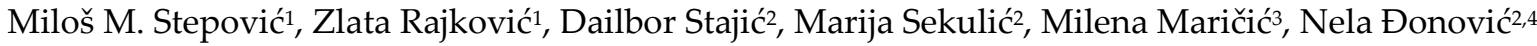 \\ ${ }^{1}$ Univerzitet u Kragujevcu, Fakultet medicinskih nauka, Kragujevac, Srbija \\ ${ }^{2}$ Univerzitet u Kragujevcu, Fakultet medicinskih nauka, Departman za higijenu i ekologiju, \\ Kragujevac, Srbija \\ ${ }^{3}$ Medicinski koledž primenjenih nauka u Zemunu, Beograd, Srbija \\ ${ }^{4}$ Institut za javno zdravlje, Kragujevac, Srbija
}

\section{SAŽETAK}

Cilj studije je određivanje povezanosti nivoa depresije $\mathbf{i}$ oralnog zdravlja, oralnih navika $\mathbf{i}$ subjektivnih osećaja u regiji usta i zuba kod studenata završne godine studija medicine.

Ukupno 103 studenta završne godine studija medicine Fakulteta medicinskih nauka, Univerziteta u Kragujevcu, učestvovalo je $u$ istraživanju. Korišćena su dva upitnika u istraživanju - Bekov inventor depresije II i upitnik oralnog zdravlja za odrasle. Statistička analiza urađena je programom SPSS, verzija 21. Hi-kvadrat test korišćen je za procenu i statistički značajni rezultati bili su oni sa p vrednošću manjom od 0,05 .

Nije bilo statistički značajne razlike između nivoa depresije kod muškaraca i žena. Procentualno, 21,4\% studenata imalo je depresiju. Korelacija između depresivnih nivoa i oralnih pokazatelja ukazala je na to da su učestalost pranja zuba i izbegavanje osmehivanja bili značajno različiti među ženskim studentima, sa procenjenim različitim nivoima depresije. Problemi sa odgrizanjem hrane i problemi u socijalnoj interakciji bili su značajno različiti kod muškaraca i žena.

Depresija je prisutna kod studenata završnih godina studija medicine i utiče na samoprocenu oralnog zdravlja studenata. Programi promocije usmereni na populaciju mladih mogu pomoći u unapređenju njihovih stavova i ponašanja vezanih za oralno zdravlje.

Ključne reči: depresija, oralno zdravlje, student medicine, mentalno zdravlje, Srbija 